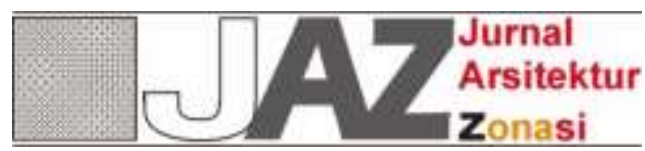

http://ejournal.upi.edu/index.php/jaz/ - e-mail: jurnal.zonasi@gmail.com dan jurnal_zonasi@upi.edu DOI: http://dx.doi.org/10.17509/jaz.v1i1.11542

\title{
TATANAN TERITORIAL DALAM PROSES TRANSFORMASI HUNIAN
}

\author{
Article History: \\ First draft received: \\ 30 April 2018 \\ Revised: \\ 6 June 2018 \\ Accepted: \\ 27 June 2018 \\ Final proof received: \\ Print: \\ 29 June 2018 \\ Online \\ 30 June 2018
}

Indah Susanti ${ }^{1}$, Nitih Indra Komala Dewi ${ }^{2}$, Asep Yudi Permana ${ }^{3}$

1,2 Departemen Pendidikan Teknik Arsitektur, FPTK, Universitas Pendidikan Indonesia

3. Koresponden Author Departemen Pendidikan Teknik Arsitektur, FPTK,

Universitas Pendidikan Indonesia

Jl. Dr. Setiabudhi No. 207, Kota Bandung 40154, Indonesia

Email: indahsusanti@upi.edu

nitih@upi.edu

yudi.permana@upi.edu

Abstract: The phenomena of transformation in a built environment in both urban and rural scales is a dynamic process that changes occur naturally. Transformation can be seen from the physical, territorial, and cultural aspects, where all three have a very close relationship that affects each other. The territorial aspect of the transformation process is discussed in this paper. The order of Residential Territory in a settlement is very dependent on the activity of its inhabitants. The occupants of the house here become an agent that can control the space. Space control is a decision for anyone who can enter or exit space in a territory and decisions that can change or shift the function of existing space into other functions. Occupancy transformation occurs gradually when an interest and needs must be met. Household business activities / Home Base Enterprises (HBEs) that rely on households to be one cause of the transformation process of occupancy. The need for economic improvement and sustainability encourages people to engage in HBEs activities that mostly use residential space for business activities. Occupancy at the settlement in Kampung Mahmud is a case study in this paper, most of which is used for the activities of small furniture and small shop (HBEs). This paper aims to examine and observe the territorial structure in the process of residential transformation in the activities of Home Base Enterprises (HBEs), which in the transformation process causes changes in space usage and territorial shifts for residential functions with business functions.

Keywords: Territory, Space Use, Transformation, HBEs Dwelling, Kampung Mahmud.

Abstrak: Fenomena transformasi pada suatu lingkungan binaan baik dalam skala perkotaan maupun pedesaan merupakan suatu proses dinamis yang perubahannya terjadi secara alami. Transformasi dapat dilihat dari aspek fisik, teritorial, dan budaya, dimana ketiganya memiliki hubungan yang sangat erat yang mempengaruhi satu sama lain. Aspek territorial dalam proses transformasi menjadi bahasan dalam tulisan ini. Tatanan Teritori hunian pada suatu permukiman sangat bergantung pada aktivitas penghuninya. Penghuni rumah disini menjadi suatu agen yang dapat mengontrol ruangnya. Kontrol ruang berupa keputusan bagi siapa saja yang dapat masuk atau keluar ruang dalam suatu teritori dan keputusan yang dapat merubah atau menggeser fungsi ruang yang ada menjadi fungsi lainnya. Transformasi hunian terjadi secara berangsur-angsur ketika suatu kepentingan dan kebutuhan harus dipenuhi. Kegiatan usaha rumah tangga / Home Base Enterprises (HBEs) yang bertumpu pada rumah tangga menjadi salah satu penyebab dari adanya proses transformasi hunian. Kebutuhan akan peningkatan dan keberlanjutan ekonomi mendorong masyarakat untuk melakukan kegiatan HBEs yang sebagian besar menggunakan ruang tempat tinggal untuk kegiatan usaha. Hunian pada permukiman di Kampung Mahmud menjadi studi kasus dalam tulisan ini, yang sebagian besar huniannya digunakan untuk kegiatan usaha pengrajin mebel dan warung kecil (HBEs). Tulisan ini bertujuan untuk mengkaji dan mengamati struktur teritori dalam proses transformasi hunian pada kegiatan Home Base Enterprises (HBEs), dimana dalam proses transformasinya menyebabkan perubahan penggunaan ruang dan pergeseran wilayah teritori untuk fungsi rumah tinggal dengan fungsi kegiatan usaha.

Kata kunci: Teritori, penggunaan ruang, transformasi, hunian HBEs, Kampung Mahmud. 


\section{Pendahuluan}

Permukiman adalah konteks dan tujuan kearah perubahan yang lebih baik. Hunian merupakan bagian dari permukiman yang dipandang sebagai proses, tidak hanya sekedar bentuk fisik tetapi memiliki unsurunsur lain didalamnya, termasuk pengaruh yang dihasilkan oleh penghuni (Turner dan Fichter, 1972; Ramel, 2010). Perubahan dalam ranah lingkungan binaan kearah yang lebih baik merupakan alasan atas kebutuhan bertransformasi. Kategori dari transformasi diantarnya revitalisasi, gentrification, regeneration, dll (Pratiwi, 2012). Transformasi dapat dilihat dari aspek fisik, teritorial, dan budaya, dimana ketiganya memiliki hubungan yang sangat erat yang mempengaruhi satu sama lain (Habraken, 1998). Aspek territorial dalam proses transformasi menjadi bahasan yang akan diamati. Tatanan Teritori hunian pada suatu permukiman sangat bergantung pada aktivitas penghuninya. Penghuni rumah disini menjadi suatu agen yang dapat mengontrol ruangnya. Transformasi hunian terjadi secara berangsur-angsur ketika suatu kepentingan dan kebutuhan harus dipenuhi.

Kegiatan usaha rumah tangga / Home Base Enterprises (HBEs) yang bertumpu pada rumah tangga menjadi salah satu penyebab dari adanya proses transformasi Hunian (Soegiono, Setijanti, \& Faqih, 2010). Hunian pada permukiman di Kampung Mahmud menjadi studi kasus dalam tulisan ini, yang sebagian besar huniannya digunakan untuk kegiatan usaha pengrajin mebel dan warung kecil (HBEs). Proses transformasi berlangsung ketika masyarakat Kampung Mahmud mengalami perubahan mata pencaharian, yang pada awalnya adalah bergerak dalam bidang pertanian dan perkebunan menjadi pengrajin mebel. Hal tersebut dikarenakan adanya program normalisasi sungai Citarum yang diselenggarakan oleh pemerintah kabupaten setempat yang mengakibatkan hilangnya sebagian besar lahan pertanian dan perkebunan masyarakat Kampung (Purnama, 2012). Dalam rangka untuk meningkatkan dan melanjutkan perekonomian keluarga, masyarakat menyelenggarakan HBEs yaitu usaha bertumpu pada rumah tangga.

Adanya kegiatan HBEs yang sebagian besarnya kegiatannya adalah pada rumah tinggal, menyebabkan perubahan pada tatanan teritori hunian. Tatanan teritori disini dilihat pada penggunaan ruang luar di Kampung tersebut yang terdiri dari sirkulasi jalan utama, sirkulasi jalan lingkungan, halaman, teras, dan rumah. Berdasarkan paparan sebelumnya penulis akan mengkaji dan mengamati tatanan teritori dalam proses transformasi hunian dalam kegiatan Home Base Enterprises (HBEs), dimana dalam proses transformasinya menyebabkan perubahan penggunaan ruang dan pergeseran wilayah teritori.

\subsection{Pemahaman Mengenai Transformasi}

Transformasi memiliki makna sejenis dengan alteration, change, conversion, revolution, renovation, and makeover. Dimana memiliki arti yang sama adalah perubahan dan pembaharuan (Pratiwi, 2013). Transformasi merupakan proses perubahan suatu bentuk menjadi bentuk baru yang mempertimbangkan aspek ruang dan waktu yang dijalani secara bertahap, dimana bentuk baru tersebut menjadi tahap akhir dari proses perubahan (Webster Dictionary, 1970; Pratiwi, 2012). Perubahan fisik dipengaruhi oleh faktor perubahan non fisik berupa perubahan budaya penghuni atau masyarakat itu sendiri, perubahan sosial, dan perubahan ekonomi dan politik. (Rosi, 1982; Sari, 2007; Pratiwi, 2012).

Sehingga, makna transformasi adalah suatu proses perubahan secara bertahap dari suatu bentuk menjadi bentuk baru yang dipengaruhi oleh faktor fisik maupun faktor non fisik yaitu berupa perubahan budaya, sosial, ekonomi, dan politik dengan mempertimbangkan aspek ruang dan waktu.

Berdasarkan makna dari transformasi adalah suatu proses, maka beberapa tahapan dalam transformasi adalah 1) Perubahan terjadi secara bertahap; 2) Waktu memulai dan sampai kapan proses perubahan berakhir tidak dapat diprediksi, tergantung pada faktor yang mempengaruhinya; 3) Proses perubahan berjalan secara komprehensif dan saling berkesinambungan; 4) Nilai- nilai perilaku pada masyarakat berkaitan erat dengan terjadinya proses perubahan pada lingkungan. Transformasi dalam prosesnya berkaitan erat dengan waktu dan kondisi sosial budaya masyarakat setempat, dalam proses perubahannya tidak lepas dari aktivitas atau kegiatan yang berlangsung pada saat itu (Alexander, 1987; Pakilaran, 2006; Pratiwi, 2012).

Proses transformasi tidak lepas dari beberapa faktor yang mempengaruhinya. Menurut Habraken, (1976) faktor yang mempengaruhi transformasi yaitu 1) Kebutuhan akan identitas dan eksistensi diri dalam lingkungannya; 2) Perubahan gaya hidup (life style), yang dipengaruhi oleh singgungan dengan budaya lain; 3) Penggunaan teknologi baru, dimana sekarang modernitas teknologi sudah mulai masuk untuk mempengaruhi perubahan fisik lingkungan; 4) adanya emosional masyarakat untuk mengikuti perkembangan jaman atau mengikuti mode, dimana perubahan akan sangat cepat terjadi karena sesuatu yang masih dapat digunakan sudah dipaksa untuk dirubah demi mengikuti mode padahal yang dahulu masih dapat digunakan (Pakilaran, 2006; Pratiwi, 2012). 
Faktor lain yang mempengaruhi transformasi menurut Rosi, (1982) dan Sari, (2007) adalah : 1) Adanya perubahan sosial, 2) Perubahan budaya, 3) Perubahan ekonomi, 4) Perubahan politik (Pratiwi, 2012). Transformasi memiliki karakter yang berbeda-beda, yang dikelompokkan dalam empat kategori di antaranya 1) Transformasi bersifat topologikal, artinya perubahan yang terjadi adalah perubahan pada komponen pembentuk ruang yang memiliki fungsi ruang yang sama; 2) Transformasi bersifat gramatikal (ornamental), artinya perubahan yang terjadi mencerminkan nilai budaya masyarakat; 3) Transformasi bersifat reversal (kebalikan), artinya perubahan yang terjadi dilakukan dengan membalikkan citra pada objek yang akan ditransformasikan; 4) Transformasi bersifat distorsi (merancukan), artinya perubahan yang dilakukan dengan memberikan kebebasan perancang dalam merubah suatu objek (Laseau, 1980; Sembiring, 2006; Pratiwi, 2012).

Transformasi berlangsung secara berurutan dimana satu sama lain memiliki keterikatan erat dengan lingkungan binaan. Lingkungan binaan beserta elemen yang ada didalamnya akan mengalami suatu tahap perubahan yang dipengaruhi oleh aktivitas penghuninya dan disesuaikan terhadap kebutuhan dan perkembangan zaman, perubahan tersebut dipandang sebagai konsekuensi dari perubahan gaya hidup (life style). Perubahan gaya hidup diakibatkan oleh adanya pergeseran atau perubahan orientasi budaya dari nilainilai sosial budaya yang menjadi dasar atau pedoman. Pergeseran nilai-nilai budaya merupakan sebuah bentuk konsekuensi dari berubahnya cara pandang dari sekelompok masyarakat. Proses transformasi berakhir pada perubahan cara pandang sekelompok masyarakat yang memberikan kontribusi terhadap perubahan pada bentuk fisik dari elemen-elemen bangunan (Rapoport, 1990; Sari, 2007; Pratiwi, 2012).

Menurut Rossi, (1984) Arsitektur bukan hanya sesuatu yang bisa dilihat tetapi juga merupakan proses konstruksi permukiman yang berkembang setiap saat. Perubahan sebuah kota, kampung, atau permukiman sangat dipengaruhi oleh perubahan aktivitas dan gaya hidup dari masyarakatnya, dimana dalam perubahan tersebut dibutuhkan penyesuaian antara kebutuhan masyarakat dengan kondisi lingkungannya (Sari, 2006). Perubahan aktivitas dan gaya hidup sekelompok masyarakat dapat dipengaruhi oleh potensi atau daya tarik yang ada dikawasan tersebut yang dapat dijadikan sebagai objek wisata dan dapat mendukung kebutuhan dan perekonomian masyarakat setempat (Ombeni dan Deguchi, 2009). Selain itu juga didukung oleh modernitas teknologi yang masuk dalam sebuah permukiman karena adanya akses wisata dikawasan tersebut.

\subsection{Pemahaman Mengenai Tatanan Teritorial dalam Proses Transformasi}

Teritori merupakan pola perilaku yang berhubungan dengan kepemilikan seseorang maupun sekelompok orang pada lingkungan tertentu (Hendro, 1998). Sedangkan menurut Habraken, (1998) ruang dibawah aturan atau pengawasan dimaknai sebagai pengertian teritorial "Space under control is territorial" (Bukit, Hanan, dan Wibowo, 2012). Dengan demikian, teritori dapat diartikan sebagai sebuah unit dari sebuah ruang yang memiliki aturan (control) yang berhubungan dengan pola perilaku dan kepemilikan. Kedalaman teritorial dapat diukur dengan jumlah batas perlintasan yang diperlukan untuk bergerak dari wilayah paling luar ke wilayah yang paling terdalam. Hal tersebut ditunjukkan dalam Diagram Depth Sequence.

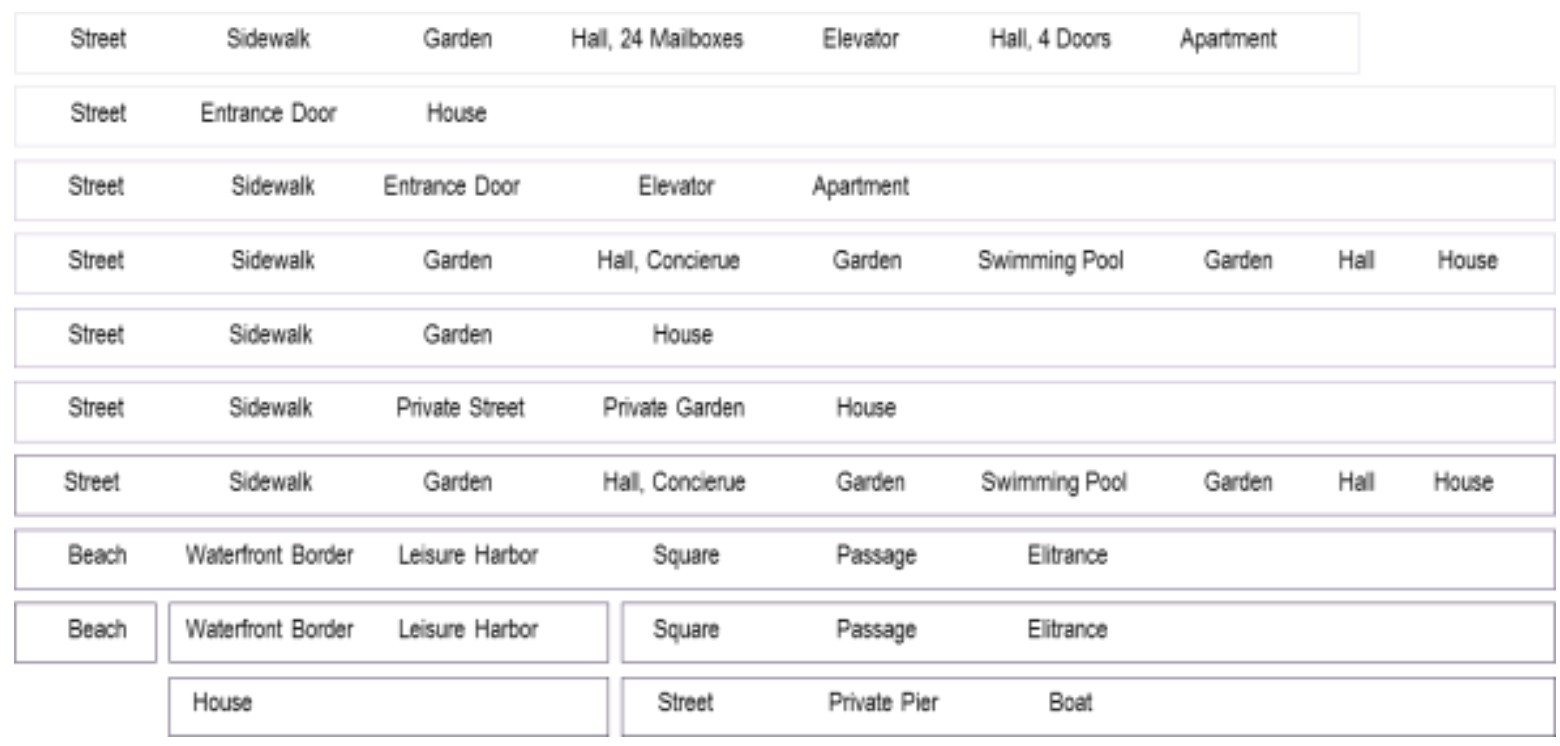

Gambar 1. Urutan Kedalaman Teritori

Sumber : (Habraken, 1998; Scheerlinck, 2012) 
Diagram Depth Sequence diatas menjelaskan hubungan prinsip untuk memasuki transisi antara ruang privat dan publik yang digambarkan dengan cara yang berbeda untuk dapat mengakses wilayah-wilayah teritori.

\section{Peningkatan Struktur Teritori}

Pergeseran teritori dapat berupa peningkatan atau penurunan zona /ruang, sesuai dengan karakteristik dan dinamika lingkungan binaan tertentu. Peningkatan kedalaman teritorial dapat disebabkan oleh peningkatan kepadatan (baik manusia maupun aktivitas) di lingkungan permukiman, salah satunya dapat disebabkan oleh adanya migrasi penduduk (N.J. Habraken, 1998).

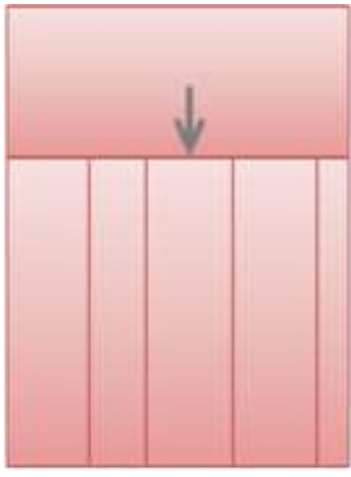

a

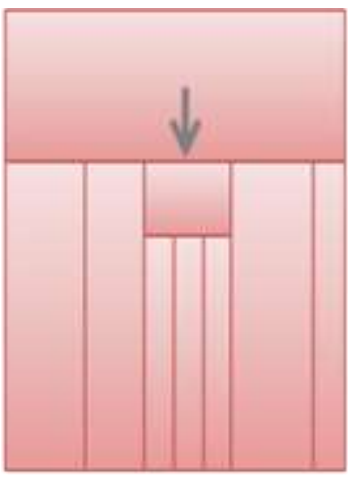

b1

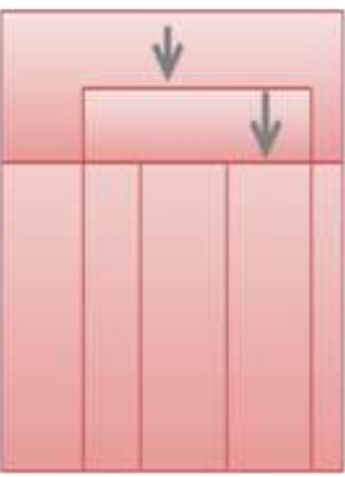

b2

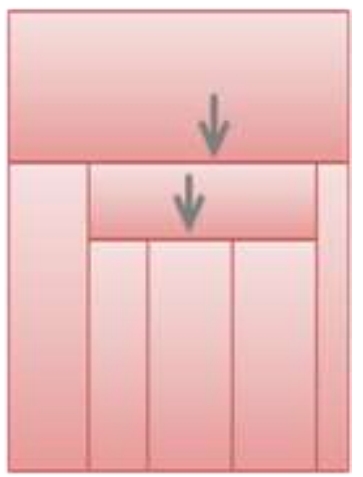

b3

Gambar 2. Prinsip diagram skematik peningkatan struktur teritori Sumber : (N.J. Habraken, 1998)

Transformasi dari a ke b1 : An included territory may in turn encompass included territories

Transformation from a to b2: Included territories occupy public space to make it their own

Transformation from a to b3: Included territories sacrifice some of their own space to make shared public

Pada prinsip diagram skematik di atas menjelaskan adanya peningkatan struktur teritori dijabarkan dengan tiga pergeseran teritori diantaranya adalah :

* Transformasi dari a - b1 : Perubahan untuk mewujudkan intensifikasi penggunaan ruang, yang berarti pembagian wilayah, sebuah zona ruang bersama (shared space) diciptakan sebelum memasuki teritori baru. ("Top Down").

* Transformasi dari a - b2 : Perubahan dalam menggunakan ruang publik yang ada untuk menciptakan ruang publiknya sendiri.("Bottom Up").

* Transformasi dari a - b3 : Perubahan untuk menciptakan ruang bersama (shared space) yang terjadi karena mengorbankan atau mengambil beberapa ruang privat yang ada untuk zona bersama.

Contoh sederhana yang terjadi pada lingkungan binaan yang menggambarkan pergeseran adanya peningkatan teritori adalah penambahan ruang pada hunian.

Misalnya : Pada awalnya memiliki 2 tingkatan teritori di hunian tersebut, yaitu

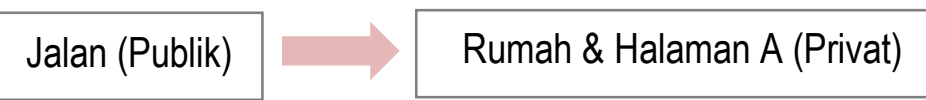

Kemudian mengalami peningkatan teritori menjadi 3 tingkatan akibat penambahan ruang atau rumah $\mathrm{B}$ \& $\mathrm{C}$

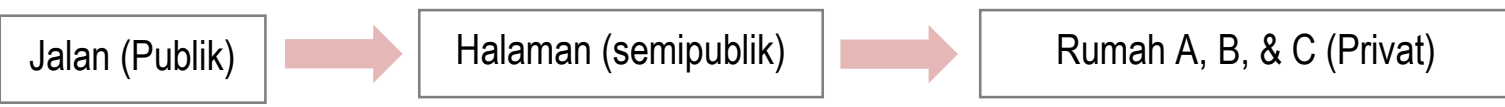

Peningkatan teritori terlihat pada halaman rumah A dapat diakses oleh penghuni rumah B dan C. 


\section{Penurunan Struktur Teritori}

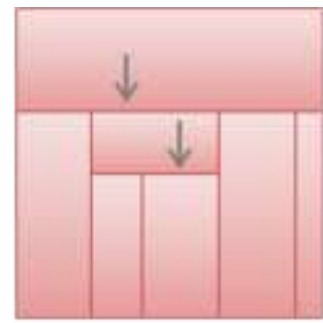

a

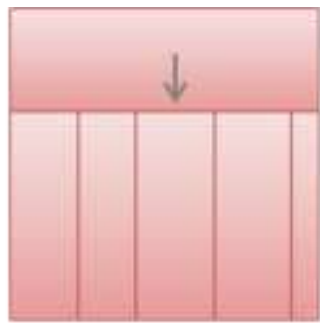

61

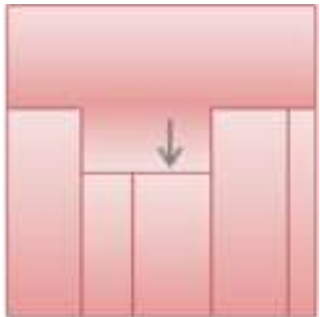

62

Gambar 3. Prinsip diagram skematik penurunan struktur teritori

Sumber : (N.J. Habraken, 1998)

Transformation from a to $b 1$ : Included territories jointly annex and divide existing shared space between themselve Transformation from a to $b 2$ : Encompassing territory invades and annexes included territory

Misalnya : Pada awalnya memiliki 3 tingkatan teritori di komplek perumahan atau permukiman dimana suatu gerbang atau gate dihilangkan untuk kepentingan tertentu, yaitu:

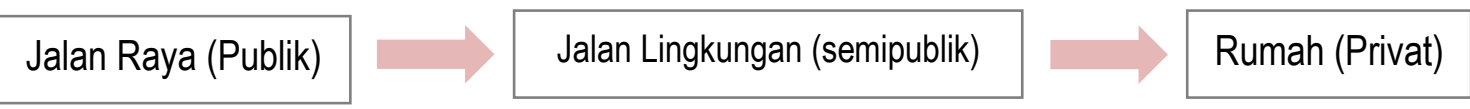

Kemudian mengalami penurunan teritori menjadi 2 tingkatan akibat hilangnya gate dalam suatu teritori.

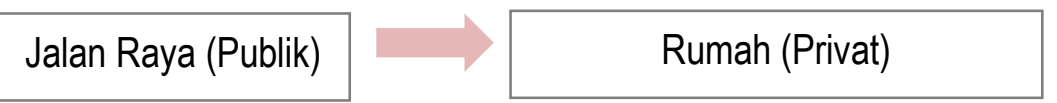

Penurunan teritori terlihat pada hilangnya gate dari suatu batas teritori.

\section{Pemahaman Mengenai Perubahan Penggunaan Ruang Pada Rumah Produktif Home Base Enterprises (HBEs)}

Rumah yang mengalami perubahan fungsi dari tempat tinggal menjadi tempat usaha dapat diartikan sebagai rumah produktif (Soegiono et al., 2010). Fungsi rumah tidak hanya sebagai hunian saja, tetapi dapat pula dimanfaatkan sebagai tempat untuk menunjang keberlanjutan ekonomi keluarga. Rumah memiliki konsep sebagai hunian atau tempat tinggal dimana fungsi-fungsi dari ruang yang ada merupakan cerminan dari perilaku penghuni. Fenomena mengenai Home Base Enterprises (HBEs) menunjukkan dualisme fungsi hunian antara fungsi tempat tinggal dengan tempat usaha, yang dalam prosesnya memberikan pengaruh terhadap penggunaan ruang dan teritori. Pengamatan mengenai transformasi penggunaan ruang hunian pada ruang dalam maupun ruang luar menggambarkan teori (Turner dan Fichter, 1972; Sari, 2006) bahwa hunian merupakan sebuah proses (Housing as a process) yang berkaitan dengan waktu, dimana teori ini menjadi dasar dalam penerapan nilai rumah dan perubahan fungsi ruang serta pergeseran daerah teritori yang mengkonsepkan hubungan antara kultur dan lingkungan binaan.

HBEs bukan merupakan suatu fenomena baru di Indonesia maupun negara-negara berkembang. HBEs menjadi salah satu strategi dalam menunjang peningkatan dan keberlanjutan aspek ekonomi yang sangat bermanfaat untuk mengantisipasi peningkatan pengangguran. Namun dari adanya kegiatan HBEs telah menyebabkan adanya penyesuaian (housing adaptation) dan penambahan ruang (housing adjustment) pada hunian. Sehingga perilaku penghuni harus dapat menyesuaikan perubahan maupun pergeseran hal-hal yang bersifat privasi. Nilai-nilai privasi dalam rumah tangga, (Anisa, 2011) menyatakan bahwa nilai privasi merupakan konsep utama dalam membatasi ruang pribadi, teritori, maupun ruang sosial. Ruang-ruang yang berada didalam maupun luar rumah mempunyai tingkatan hirarki untuk membentuk berbagai fungsi. Kegiatan yang menggunakan ruang hunian maupun halaman, untuk suatu kegiatan usaha dapat membentuk pola lingkungan kerja, sosial, peningkatan ekonomi. Kegiatan tersebut menimbulkan terjadinya perubahan ruang, pergeseran teritori dan nilai privasi penghuni. (Istiqomah, Dewi, dan Fajria, 2011) 


\section{Metode Penelitian}

Dalam melaksanakan penelitian ini, peneliti menggunakan metode kuantitatif deskriptif. Metode penelitian ini dipilih berdasarkan masalah (fenomena) yang ada yaitu berupa perubahan fungsi dalam penggunaan ruang hunian suatu lingkungan binaan yang menyebabkan pergeseran tingkatan teritori. Lingkungan binaan yang akan dibahas adalah permukiman Kampung Mahmud yang sebagian besar hunian merupakan rumah produktif pengrajin mebel dan usaha warung kecil. Dalam metode pengumpulan data mengenai penggunaan ruang hunian untuk tempat tinggal dan usaha dilakukan dengan cara observasi dan wawancara serta data sekunder yaitu beberapa literatur dan penelitian sejenis.

\section{Hasil dan Pembahasan}

\subsection{Studi Kasus : Pergeseran Struktur Teritori Pada Hunian Produktif (Home Bases Enterprises) Permukiman di Kampung Mahmud}

Kampung Mahmud merupakan permukiman yang dikelilingi oleh aliran sungai Citarum dan hamparan persawahan dan perkebunan yang luas. Banjir yang terjadi disejumlah wilayah didaerah Bandung Selatan setiap musim penghujan membuat pemerintah kabupaten Bandung melakukan normalisasi sungai yang mengakibatkan sebagian lahan pesawahan dan perkebunan hilang (Purnama, 2012) Hilangnya lahan pesawahan dan perkebunan tersebut mengakibatkan masyarakat Kampung Mahmud mengalami perubahan dari segi mata pencahariannya, yang pada awalnya sebagai petani menjadi pengrajin mebel. Kegiatan usaha pengrajin mebel termasuk dalam kategori Home Base Enterprises (HBEs), dimana tempat kegiatan kerjanya sangat bergantung pada tempat tinggal (hunian).
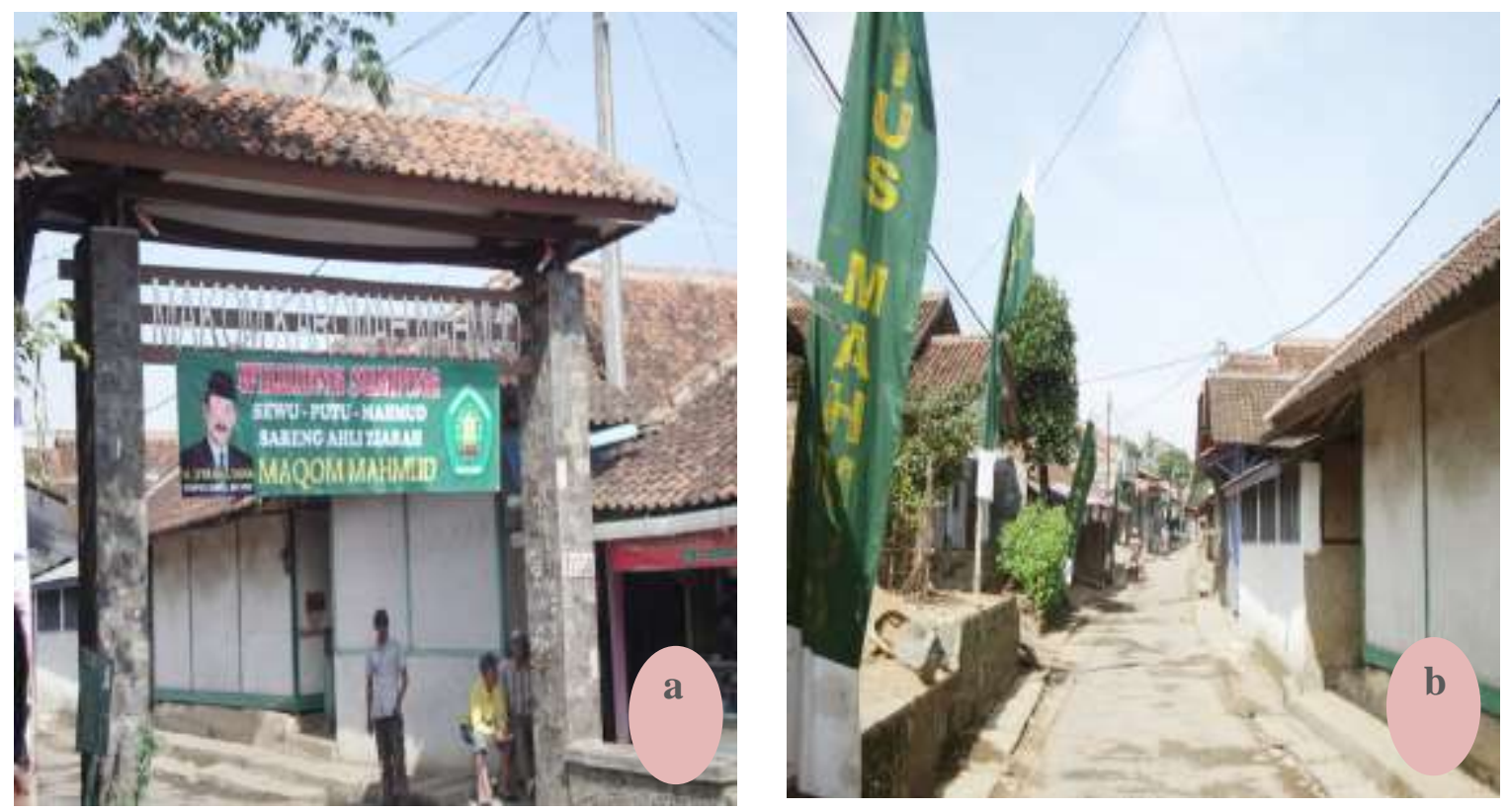

Gambar 4. (a) Gerbang (gate) Kampung Mahmud sebagai penanda dari teritorinya (b) Jalan Utama Kampung Mahmud sebagai penghubung tiap zona teritori Sumber : (Susanti, 2014)

Beberapa warga yang kehilangan mata pencahariannya segera memutuskan untuk dapat menyambung keberlanjutan ekonominya dengan menjadi pengrajin mebel. Secara berangsur-angsur perubahan mata pencaharian wargapun terjadi di Kampung Mahmud, dimana mempengaruhi perubahan dalam penggunaan ruang tempat tinggal dan tempat usaha yang diakibatkan oleh Home Base Enterprises (HBEs) pengrajin mebel. Saat ini sebagian besar hunian memiliki dualisme fungsi yaitu fungsi untuk tempat tinggal dan fungsi untuk kegiatan usaha. Mata pencaharian masyarakat sebagian besar adalah pengrajin mebel dan pedagang kecil yang kegiatannya berupa warung kecil yang menyatu dengan hunian tempat tinggal. Berdasarkan pemaparan tersebut, dalam tulisan ini akan dikaji mengenai pergeseran teritori dalam penggunaan ruang pada usaha pengrajin mebel dan warung kecil di Kampung Mahmud. 

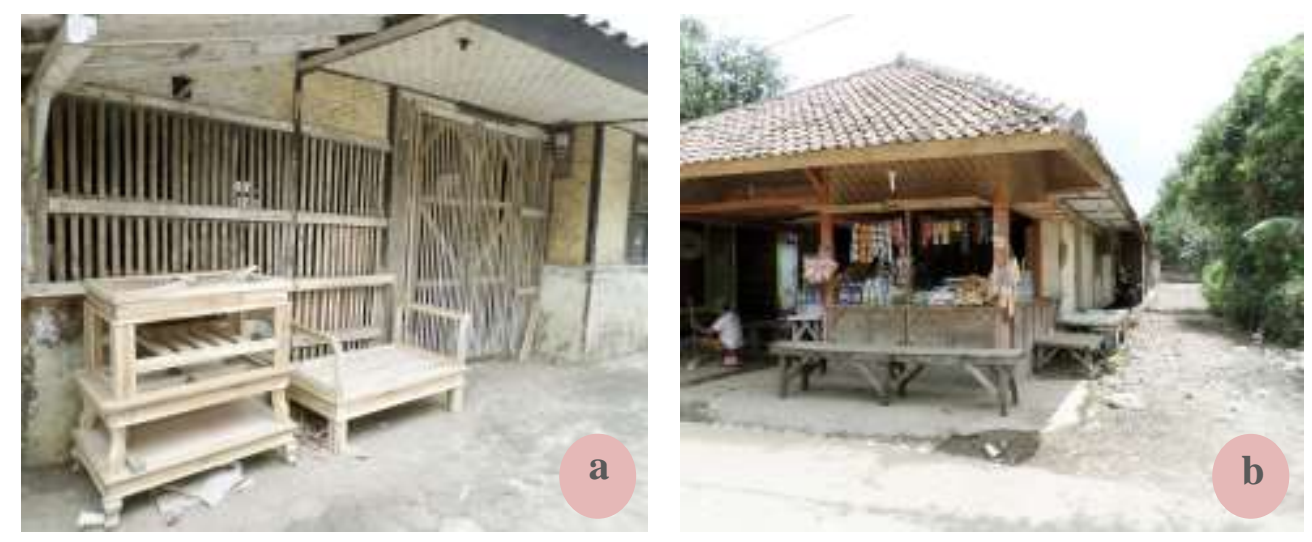

Gambar 5. (a) Usaha pengrajin Mebel (b) Usaha Dagang Kecil

Sumber : (Susanti, 2014)

Pada tahun 1997 permukiman ini mengalami perkembangan fisik dan sosial masyarakatnya yang ditandai oleh keberadaan ruang sosial atau ruang bersama (shared space) pada kampung tersebut (Purnama, 2008). Shared space pada lingkungan permukiman mengalami perubahan dan pergeseran dalam struktur teritorinya pada tingkat masing-masing unit hunian terutama pada bagian teras (golodog) dan halaman (buruan) yang menciptakan shared space antara sesama penghuni rumah tinggal dalam satu keluarga maupun penghuni tetangga di sebelah rumah. Share space tersebut antara lain terbentuk karena kepentingan akan usaha pengrajin mebel yang sering menggunakan teras dan halaman untuk bekerja. Selain usaha pengrajin mebel, sebagian warga memilih untuk berdagang yang ditempatkan didepan, ataupun samping sudut rumah. Pada warung kecil ini terjadi pula interaksi antara warga. Baik itu sesama warga asal kampung ataupun warga luar yang sering menggunakan warung tersebut untuk beristirahat saat kunjungan ziarah ke Makom Mahmud.
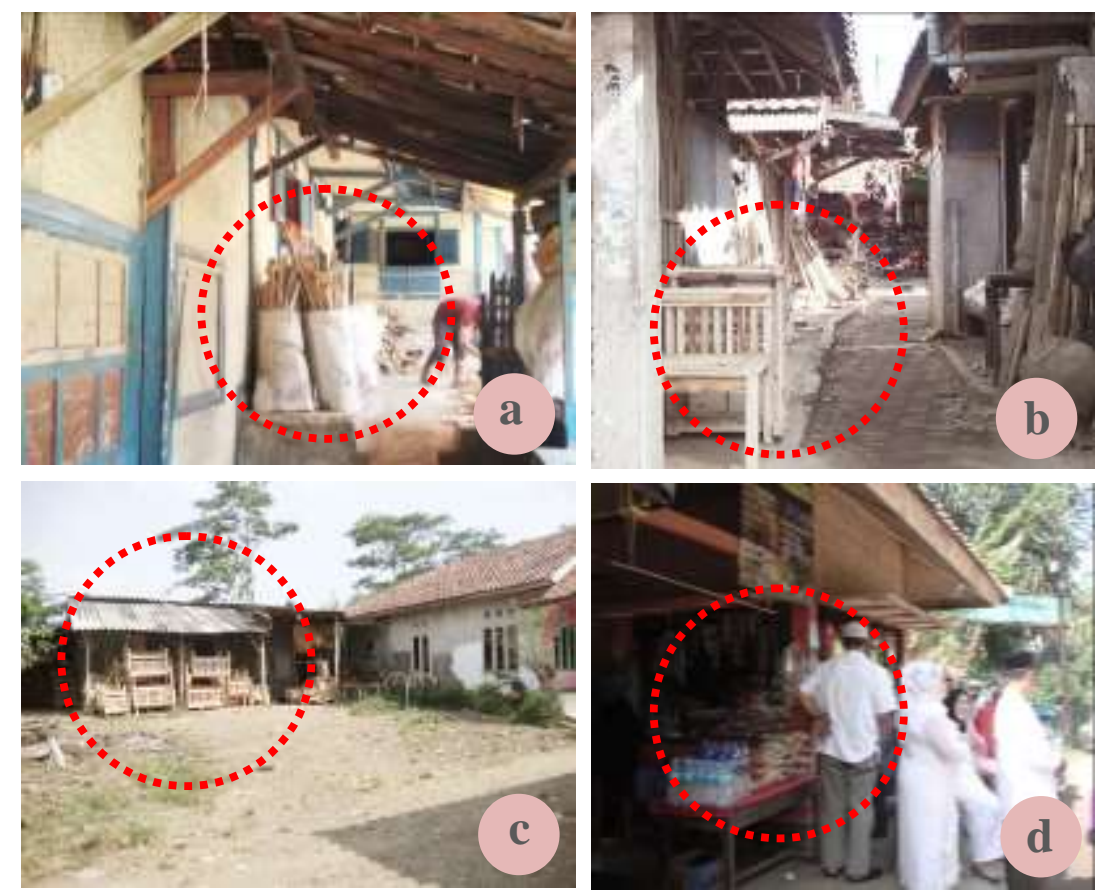

Gambar 6. Penggunaan shared space pada hunian Sumber : (Susanti, 2014)

Berdasarkan gambar a, b, c, dan d menunjukkan adanya pergeseran fungsi ruang dan penggunaan shared space pada hunian. Gambar a menunjukkan penggunaan fungsi teras dengan dimensi yang cukup besar untuk kegiatan bekerja. Gambar b menunjukkan adanya penggunaan ruang pada teras 
dengan dimensi teras yang sangat sempit untuk dijadikan tempat penyimpanan barang hasil produksi. Gambar c menunjukkan penggunaan halaman (buruan) untuk kegiatan kerja. Gambar d. menunjukkan space share yang terbentuk dari usaha warung kecil, interaksi antar warga kampung dan luar kampung terjadi disini.

Teras berfungsi sebagai akses keluar masuk hunian dan difungsikan juga sebagai tempat berkomunikasi dengan tetangganya. Selain diteras komunikasi antar warga berlangsung juga di halaman (buruan) yang sekaligus sebagai tempat bekerja para penghuni permukiman yang mata pencahariannya sebagai pengrajin mebel. Berdasarkan pergeseran fungsi ruang dan penggunaan shared space pada hunian, maka diperoleh beberapa tatanan teritori pada hunian di permukiman Kampung Mahmud. Gambar a dan b menunjukkan hunian produktif yang berada pada jalan lingkungan, sedangkan gambar $\mathrm{c}$ dan $\mathrm{d}$ menunjukkan hunian produktif yang berada pada jalan utama.

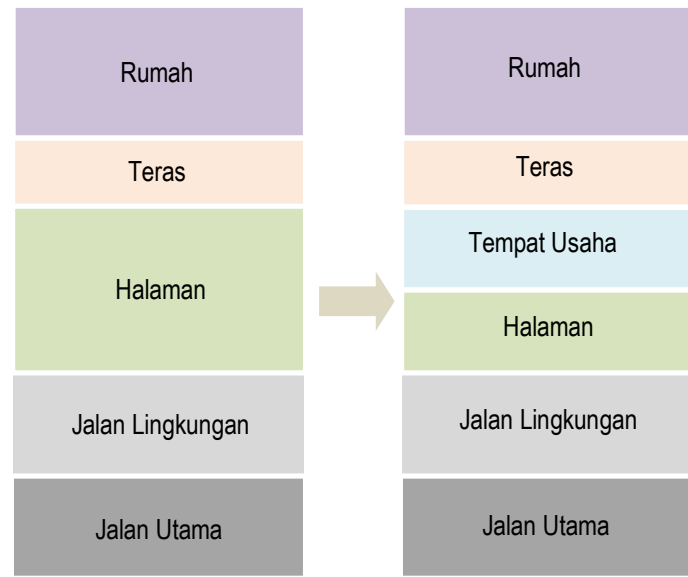

a

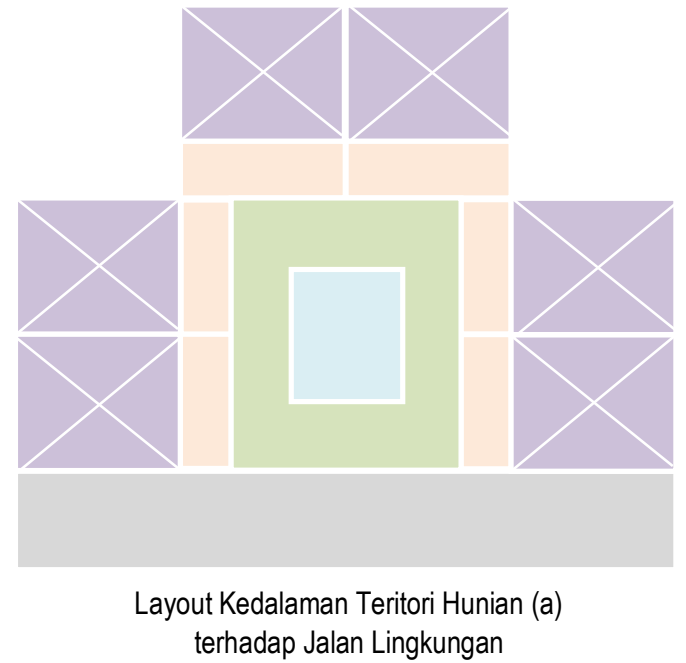

terhadap Jalan Lingkungan

Gambar 7a Layout Kedalaman Teritori Hunian (a) terhadap Jalan Lingkungan Sumber: (Susanti, 2014)

Pada gambar 7a, urutan kedalaman teritori mengalami peningkatan dalam tingkatan teritori yang pada awalnya terdiri dari 5 tingkatan menjadi 6 tingkatan dikarenakan adanya penambahan fungsi ruang sebagai tempat kerja pada halaman.

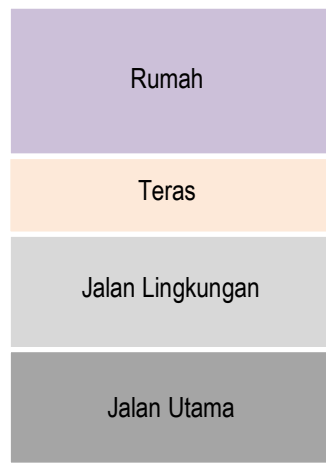

b

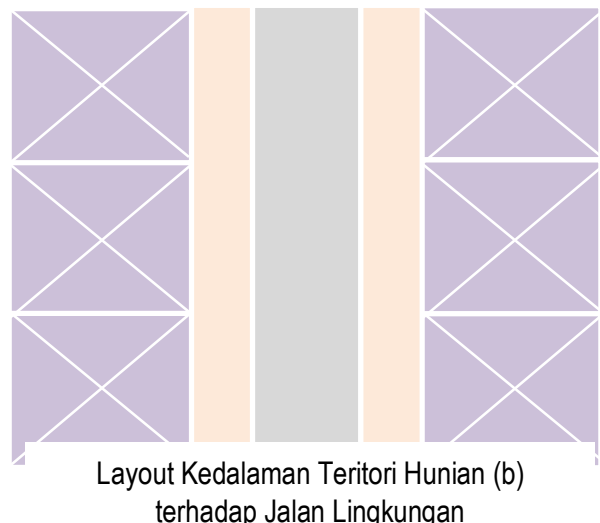

terhadap Jalan Lingkungan

Gambar 8b Layout Kedalaman Teritori Hunian (b) terhadap Jalan Lingkungan Sumber: (Susanti, 2014) 
Pada gambar $8 \mathrm{~b}$, urutan kedalaman teritori berada pada 4 tingkatan, dimana tempat usaha bergabung dengan teras, sebagai bentuk peningkatan teritori yang menggunakan ruang publik (teras) untuk tempat kerja bersama.
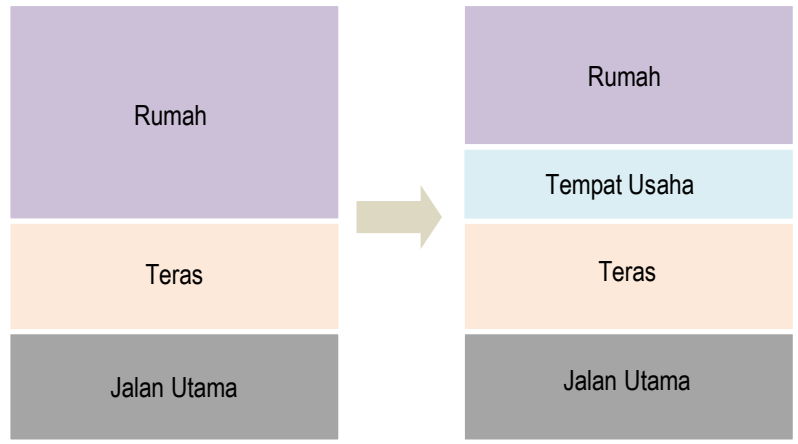

c

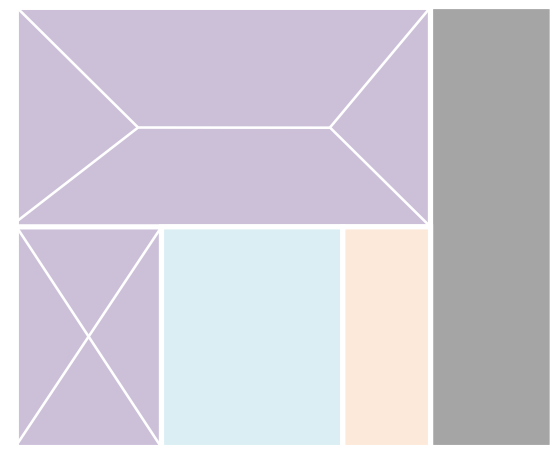

Layout Kedalaman Teritori Hunian (c) terhadap Jalan Utama

Gambar 9c Layout Kedalaman Teritori Hunian (c) terhadap Jalan Lingkungan

Sumber: (Susanti, 2014)

Pada gambar 9c, urutan kedalaman teritori mengalami peningkatan dalam tingkatan teritori yang pada awalnya terdiri dari 3 tingkatan menjadi 4 tingkatan dikarenakan adanya penambahan ruang untuk tempat usaha, dimana tempat tersebut diambil dari daerah teritori huniannya, mengambil wilayah privat untuk publik.

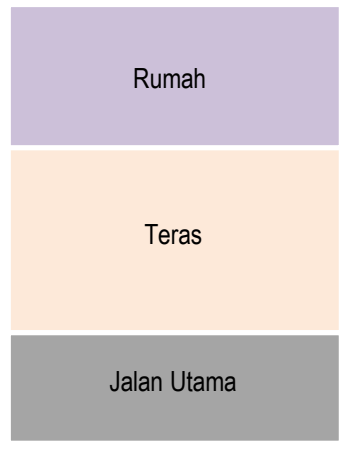

d

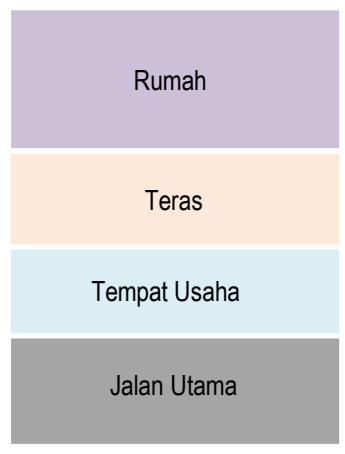

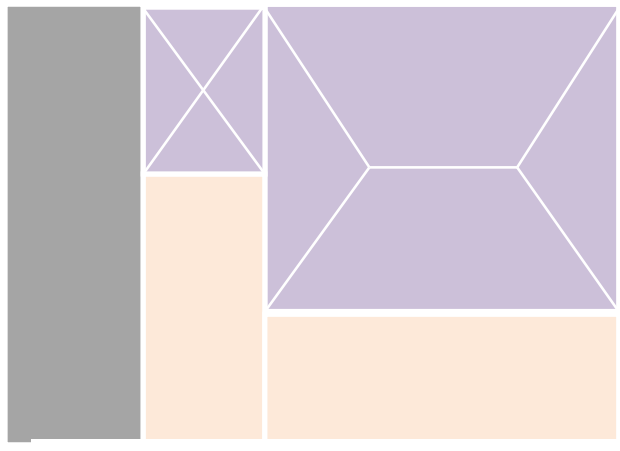

Layout Kedalaman Teritori Hunian (d) terhadap Jalan Utama

\section{Gambar 10d. Tipe Penggunaan Ruang Menunjukkan Urutan Kedalaman Teritori}

Sumber : (Susanti, 2014)

Pada gambar 10d, urutan kedalaman teritori mengalami peningkatan dalam tingkatan teritori yang pada awalnya terdiri dari 3 tingkatan menjadi 4 tingkatan dikarenakan, adanya penambahan ruang untuk tempat usaha, dimana tempat tersebut diambil dari daerah teritori huniannya, mengambil wilayah publik untuk kepentingan publik. Berdasarkan gambar a, b, c, dan d semuanya menunjukkan tipe penggunaan ruang yang menunjukkan urutan dari kedalaman teritori.

Teras, halaman dan jalan kampung menjadi ruang yang mengalami perubahan dan pergeseran struktur teritori untuk mendukung kegiatan HBEs masyarakat Kampung. Dalam proses transformasinya tidak lepas dari kontrol ruang yang dilakukan oleh masyarakat Kampung sendiri yang menciptakan kedalaman dari struktur teritorinya sendiri. Dalam buku habraken diterangkan bahwa "Teritorial Order" berkaitan dengan kontrol ruang. Kontrol ruang disini berupa keputusan siapa dan apa yang dapat masuk atau keluar ruang / zona dari suatu teritori. Setiap hierarki organisasi dari satu wilayah mengandung wilayah-wilayah lainnya. Menunjukkan bagaimana lingkungan terdiri dari rumah pribadi dan taman, dan rumah-rumah pribadi terdiri dari ruang-ruang dikendalikan oleh manusia. 


\section{Kesimpulan}

Elemen pembentuk teritori berupa nilai kepemilikan seseorang dari suatu tempat, keberadaan sistem penanda dari suatu tempat, nilai dari bentuk pertahanan pemilik, pengaturan fungsi untuk mewadahi kebutuhan dasar psikologis, kepuasan kognitif, dan kebutuhan estetika dari pemilik. Transformasi teritori ditandai oleh pergeresan teritori. Pergeseran dibagi berdasarkan pembagian teritori (Territorial Division) dan tingkatan teritori (Territorial Dept). Perubahan struktur teritori berdasarkan pembagiannya berupa Horizontal Shift dan Vertical Shift, sedangkan perubahan struktur teritori berdasarkan tingkatannya berupa Increase territory dan Decrease territory. Selain perwujudan bentuk, peran Institusi sangat berpengaruh pada perwujudan teritori.

Pada skala lingkungan binaan perubahan teritori memiliki hubungan yang erat dengan perubahan fungsi utama dari sebuah hunian seperti hunian yang memiliki dualisme fungsi yaitu sebagai tempat tinggal dan tempat untuk bekerja (Home Bases Enterprises). Pembentukan dan perubahan territori diwujudkan oleh adanya ruang-ruang bersama (shared space) yang merupakan hasil dari sistem kekerabatan masyarakat (neighborhood) setempat yang sangat tinggi. Ruang yang digunakan oleh masyarakat sebagai ruang bersama (shared space) diantaranya halaman rumah, teras rumah, ruang terbuka, dan warung-warung kecil yang terdapat di permukiman tersebut. Peningkatan Hierarki atas struktur teritori ditandai oleh keberadaan ruang kerja pada hunian atau tempat tinggal penduduk yang sebagian besar masyarakat berprofesi sebagai pengrajin mebel dengan menggunakan halaman rumah untuk bekerja. Keberadaan ruang-ruang (shared space) memberikan pengaruh terhadap integrasi dan segregasi permukiman dengan tingkatan teritori yang berbeda. Pada permukiman Kampung Mahmud terdapat 4 tipe penggunaan ruang menunjukkan urutan kedalaman teritori. Dua diantaranya hunian ada yang terletak berbatasan dengan jalan lingkungan dan hunian ada yang berbatasan dengan jalan utama. 4 tipe penggunaan ruang pada hunian yang melakukan kegiatan membuat furniture dan membuat warung kecil. Dari keempat tipe tersebut menunjukkan adanya peningkatan hirarki dari territorial suatu hunian produktif dalam kegiatan HBEs.

\section{Daftar Pustaka/ Referensi}

Alexander. (1987). Proses Transformasi. Retrieved from http://www.ar.itb.ac.id/wdp/diakses tanggal 13 Desember 2013

Anisa. (2011). Konsep Privasi Rumah-Rumah Di Kota Lama Kudus, 155-172.

Bukit, E. S., Hanan, H., dan Wibowo, A. S. (2012). Aplikasi Metode N . J . Habraken pada Studi Transformasi. Lingkungan Binaan Indonesia, 1(1), 51-62.

Habraken, N. J. (1976). Proses Transformasi. Retrieved from https://jlbi.iplbi.or.id/wp-content/ uploads/2012/07/V1N1-p051-p062-Aplikasi-Metoda-N.J.-Habraken-pada-Studi-TransformasiPermukiman-Tradisional.pdf

Habraken, N. J. (1998). The Structure of the Ordinary (Form and Control in the Built Environment). The MIT Press, Cambridge. Massachusetts London England. Retrieved from http://www.ar.itb.ac.id/ wdp/diakses tanggal 13 Desember 2013

Hendro, P. (1998). Arsitektur Psikologi Dan Masyarakat.

Istiqomah, E., Dewi, N. I. K., dan Fajria, M. (2011). Ekspresi Budaya dan Karakteristik Arsitektur : Studi Kasus Jalan Gegerkalong Girang Bandung.

Laseau. (1980). Proses Transformasi. Retrieved from http://www.ar.itb.ac.id/wdp/diakses tanggal 13 Desember 2013

N.J. Habraken. (1998). The Structure of the Ordinary (Form and Control in the Built Environment). The MIT Press, Cambridge. Massachusetts London England.

Ombeni, S., dan Deguchi, A. (2009). Transformation of Residential Units into Commercial Spaces in the Central Business District of Dar es Salaam , Tanzania, (May), 159-166. https://doi.org/10.3130/jaabe.8.159

Pakilaran. (2006). Proses Transformasi. Retrieved from http://www.ar.itb.ac.id/wdp/diakses tanggal 13 Desember 2013

Pratiwi, W. D. (2012). Proses Transformasi. Retrieved from http://www.ar.itb.ac.id/wdp/diakses tanggal 13 Desember 2013

Pratiwi, W. D. (2013). Transformasi. Retrieved from http://www.ar.itb.ac.id/wdp/diakses tanggal 13 Desember 2013

Purnama, I. (2008). Ruang Sosial dan Tatanan Massa Permukiman Kampung Mahmud dan Kampung Mancong.

Purnama, I. (2012). Ruang Sosial Dalam Stategi Keberlanjutan Permukiman. Christian University of Indonesia (UKI), Jakarta: Paper Presented at the National Seminar of "Sustainable Housing; towards 
Low Carbon City and Eco City."

Ramel, R. (2010). Pola Hunian di Kawasan Permukiman Terbatas Kota Palangka Raya.

Rapoport, A. (1990). History and Precedent in Environmental Design.

Rosi. (1982). Proses Transformasi. Retrieved from http://www.ar.itb.ac.id/wdp/diakses tanggal 13 Desember 2013

Rossi, A. (1984). The Architecture of The City. Retrieved from http://dosen.ar.itb.ac.id/wdp/wpcontent/uploads/2006/05/Perumahan dan pariwisata.pdf

Sari. (2007). Proses Transformasi. Retrieved from http://www.ar.itb.ac.id/wdp/diakses tanggal 13 Desember 2013

Sari, D. C. P. (2006). Perkembangan Pariwisata Beserta Perubahan Rumah \& Lingkungan yang diakibatkannya.

Scheerlinck, K. W. B. (2012). Depth configurations: proximity, permeability and territorial boundaries in urban projects. 4IAU $4^{a}$ Jornadas Internacionales Sobre Investigación En Arquitectura y Urbanismo. Retrieved from http://cataleg.upc.edu/record=b1363929 S1*cat

Sembiring. (2006). Proses Transformasi. Retrieved from http://www.ar.itb.ac.id/wdp/diakses tanggal 13 Desember 2013

Soegiono, B. S., Setijanti, P., \& Faqih, M. (2010). Transformasi Fungsi Hunian Akibat Usaha Berbasis Rumah Tangga.

Susanti, I. (2014). Transformasi Temporal Pada Ruang Hunian Dalam Kegiatan Wisata Religi Umat Muslim.

Turner, J. F. C., dan Fichter, R. (1972). Freedom to Build, dweller control of the housing process.

Webster Dictionary. (1970). Definisi Transformasi. Retrieved from http://www.ar.itb.ac.id/wdp/wpcontent/uploads/2009/09/definisi_transformasi_wdpratiwi.pdf 